REPORTS OF MORPHOLOGY
Official Journal of the Scientific Society of Anatomists,
Histologists, Embryologists and Topographic Anatomists
of Ukraine
journal homepage: https://morphology-journal.com

\title{
Micro- and submicroscopic changes of the cerebellar cortex 21 days after modeling the burn
}

Ohinska N.V., Nebesna Z.M., Getmanyuk I.B.

I. Gorbachevsky Ternopil National Medical University, Ternopil, Ukraine

\section{ARTICLE INFO}

Received: 14 July, 2020

Accepted: 17 August, 2020

UDC: $616.831 .711: 616-001.17$

CORRESPONDING AUTHOR

e-mail: ohinska@tdmu.edu.ua

Ohinska N.V.

\begin{abstract}
The cerebellum is a complexly organized multifunctional component of the brain and a target in numerous lesions, so the study of its morphofunctional state in various pathological conditions and burns does not lose its relevance. The aim of our study was to establish the features of micro- and submicroscopic changes in the structural components of the cerebellar cortex after 21 days under conditions of experimental thermal trauma. The experimental study was simulated on white laboratory male rats. Grade III burns were applied under thiopental-sodium anesthesia with copper plates heated in boiled water to a temperature of $97-100^{\circ} \mathrm{C}$. The size of the affected area was $18-20 \%$ of the epilated surface of the body of rats. Histological changes were studied for 21 days from the beginning of the experiment. Semi-thin sections for light microscopy were stained with methylene blue, for electron microscopy the obtained ultra-thin sections were contrasted with uranyl acetate and lead citrate according to the Reynolds method. With the help of micro- and submicroscopic studies, significant alternative changes of both neurons of all layers of the cerebellar cortex and parts of the microcirculatory tract of the organ were revealed. Neurons are disorganized, their shape is changed, there is low functional activity, due to a decrease in the area of the chromatophilic substance. Often there are cell-free areas in the ganglion layer, there is a shift of Purkinje cells deep into the granular layer, and grain cells are pushed sharply into the higher molecular layer. Thus, 21 days after the experimental thermal injury, destructivedegenerative changes of neurons of the cerebellar cortex, paravasal edema and disorders of transendothelial metabolism were established.

Keywords: cerebellar cortex, micro- and submicroscopic changes, neurons, thermal trauma.
\end{abstract}

\section{Introduction}

It is known that thermal trauma directly causes morphofunctional changes in the skin, and indirectly affects all organs and systems $[5,8,12,18]$. The burn is a strong painful stimulus, which leads to a violation of neuro-humoral mechanisms. It is established that structural and functional changes can occur in different parts of the central nervous system: vacuolation, displacement of nuclei, pyknosis, disorders of intracellular metabolism of neurons $[4,14,15$, 19]. Structural and functional reorganization of the nervous system under exogenous, stressful influences, in particular, the cerebellar cortex occurs against the background of significant vascular disorders and especially microcirculation disorders, leads to the development of dystrophic and neurodegenerative changes $[1,7,11,13,16]$.

The study of the morphofunctional state of the cerebellum in various conditions and burns, in particular, does not lose its relevance, because this organ is one of the structures of the brain that responds quickly to stressors of exogenous origin. The study of micro- and submicroscopic state of the structural components of the cerebellar cortex in severe thermal injuries is an urgent task of theoretical and practical medicine.

Therefore, the aim of the work was to establish the histological reorganization of the components of the cerebellar cortex of laboratory animals 21 days after the application of experimental thermal trauma.

\section{Materials and methods}

The experiment was performed on 15 adult white male rats, which were kept in standard vivarium conditions on a balanced diet. Animal care and all manipulations were carried out in compliance with the rules of the Strasbourg 
"European Convention for the Protection of Vertebrate Animals Used for Research and Other Scientific Purposes" and the "General Ethical Principles of Animal Experimentation" (Kyiv, 2013).

Grade III burns were applied under thiopental-sodium anesthesia with two copper plates heated in boiled water to a temperature of $97-100^{\circ} \mathrm{C}$ on the epilated surface of the skin of the animal's back for 30 seconds. The size of the affected area was $18-20 \%$ of the body surface. Experimental animals were decapitated on day 21 of the experiment.

For histological examination, pieces of cerebellar tissue were taken and fixed in a $10 \%$ solution of neutral formalin; alcohol, dehydrated and poured into paraffin blocks. Sections obtained on a rotary microtome AMR 400 were stained with hematoxylin and eosin [9]. To obtain semithin sections (1-2 $\mu \mathrm{m})$ and for electron microscopic examination, pieces of cerebellar tissue were fixed in $2.5 \%$ glutaraldehyde solution, post-fixed with $1 \%$ Osmium Tetroxide solution on phosphate buffer. Further processing was performed according to conventional methods. Semithin sections made on an LKB-3 ultramicrotome were stained with methylene blue, and ultra-thin sections were contrasted with uranyl acetate and lead citrate according to the Reynolds method [9].

Histological specimens were examined using a MIKROmed SEO SCAN optical microscope and photodocumented using a Vision CCD Camera with a histological specimen image output system. Electron microscopic study was performed in an electron microscope PEM-125K.

\section{Results}

Conducted microscopic examinations of the cerebellar cortex 21 days after thermal injury revealed a polymorphism of neuronal changes. The clear histoarchitectonics of layers of a cerebellar cortex is lost (Fig. 1).

The cells of the molecular layer undergo significant destructive changes, the shape of stellate and basket neurons is changed, they become elongated. Their nuclei are compacted, pyknotically changed. Nucleoli in neurons are rare. Significant intra- and pericellular edema of neurons is observed.

The ganglion layer loses its integrity and order. Purkinje cells are located in separate areas in many rows, or bright, cell-free, neuron-free zones are found, their migration into granular and molecular layers is noted. Neurons are disorganized, have graceful processes. The vast majority of Purkinje cells are sharply hyperchromic, the neuroplasm of which has a characteristic rich color. Individual cells have an elongated shape and are significantly destructively altered. There are also sharply hypochromic neurons with total chromatolysis, the disappearance of chromatophilic matter from the entire neuroplasm of the cell (Fig. 2).

Some Purkinje cells have a spherical shape, there are cavities, "shadow" cells, which indicates a deep irreversible malnutrition processes that occur in the cerebellar cortex

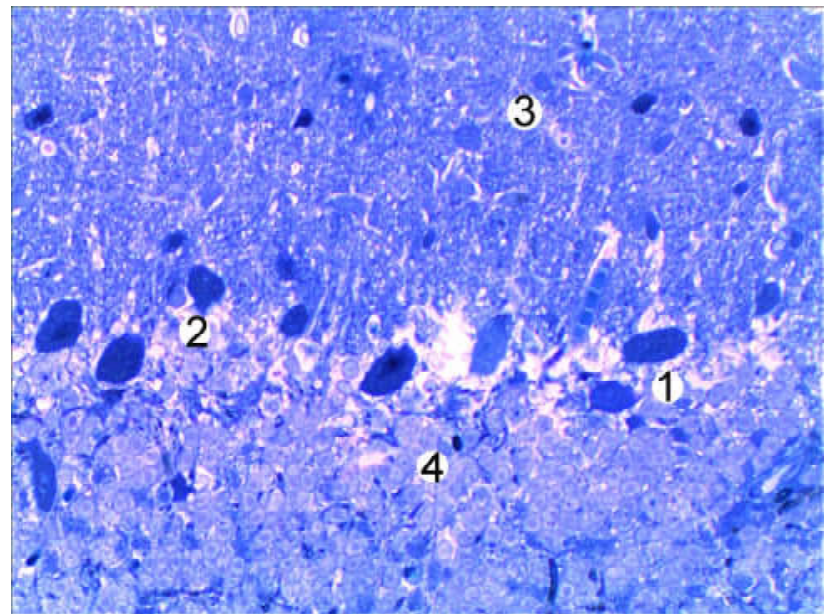

Fig. 1. Microscopic changes of the cerebellar cortex 21 days after experimental thermal injury. Disruption of the stratified arrangement of neurons (1), sharply hyperchromic Purkinje cells (2), loss of cell density and destruction of the molecular layer (3), destruction of granular layer neurons (4). Methylene blue. x200.

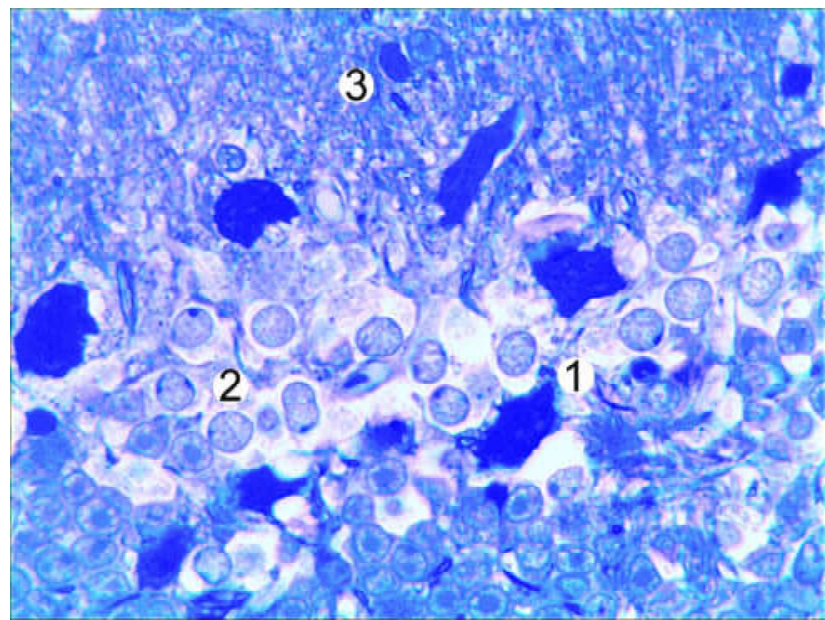

Fig. 2. Microscopic changes of the ganglion layer of the cerebellar cortex 21 days after experimental thermal injury. Multi-row arrangement of sharply hyperchromic Purkinje cells (1), migration of grain-cells into the ganglion layer (2), alteration of neurons of the molecular layer (3). Methylene blue. $\times 400$.

(Fig. 3). Neurons of the granular layer are also significantly altered, there are cell-free areas.

Micro- and submicroscopically, significant remodeling of the components of the microcirculatory tract was also established during this period of the experiment. The wall of the arterioles is compacted, homogeneous, fuzzy, destructively altered. The nuclei of endothelial cells are osmophilic, pyknotically altered with a predominance of heterochromatin in the karyoplasm, there are deep intussusception of the karyolemma. There is a destruction of organelles, which is accompanied by fragmentation of the membranes of the granular endoplasmic reticulum and mitochondria. The basement membrane is uneven, has indistinctly contoured areas (Fig. 4).

The blood supply to the venules is significant, areas of 


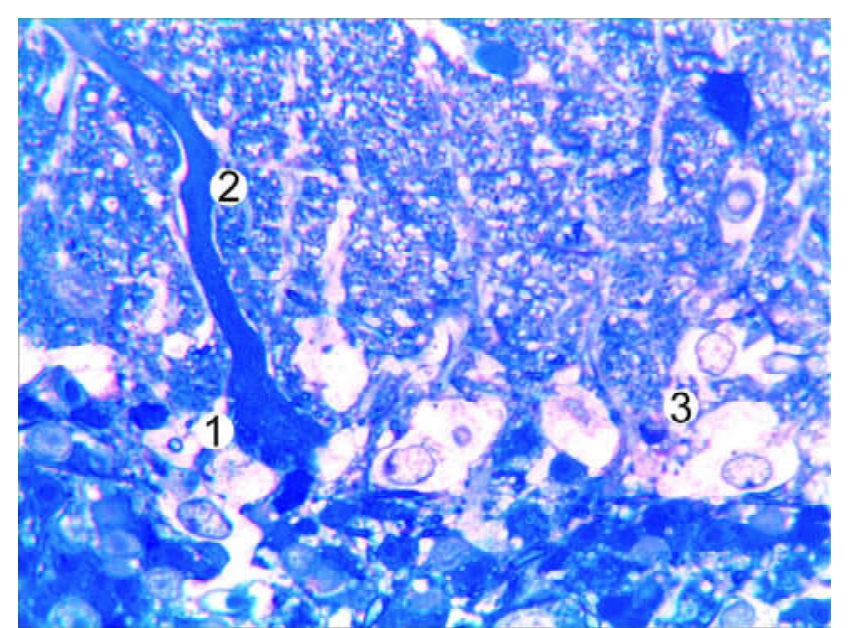

Fig. 3. Histological changes of Purkinje cells of the ganglion layer of the cerebellar cortex 21 days after experimental thermal trauma. Sharply hyperchromic Purkinje cell (1) and significant axon thickening (2), intra- and pericellular neurons edema (3). Methylene blue. $\times 400$.

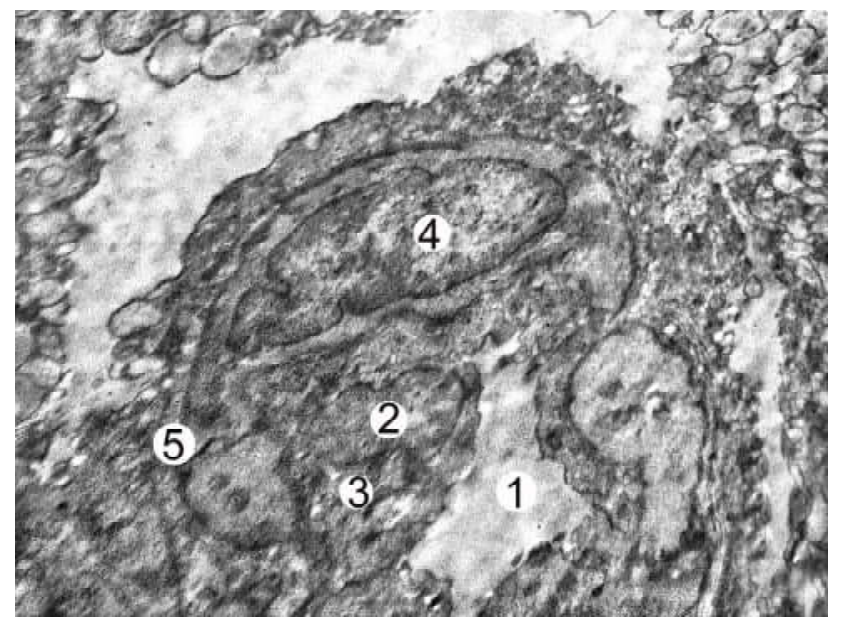

Fig. 4. Ultrastructural changes in the arterioles of the cerebellar cortex 21 days after experimental thermal injury. Narrowed lumen (1), nucleus fragment (2), edema and destruction of the endothelial cell cytoplasm (3), altered smooth myocyte (4), basement membrane (5). x9000.

wall thinning and destruction are detected, and endowment of endothelial cells into the lumen of the vessel is also detected.

The lumen of hemocapillaries is narrowed both due to edema of the cytoplasm of endothelial cells and significant perivascular edema. Their wall undergoes changes: it becomes thinner, its destruction is observed, there are blood capillaries, the lumens of which are asleep (Fig. 5).

At the ultrastructural level, the nuclei of endothelial cells are compacted, pyknotically altered, in the karyoplasm of which heterochromatin predominates. In the cytoplasm of cells there is significant destruction and damage to the membranes of the granular endoplasmic reticulum, Golgi complex and mitochondria. The tubules of the endoplasmic reticulum are dilated, fragmented, some of them are destroyed. The electronic density of the basement membrane is disturbed, in some areas it is thinned or unevenly thickened (Fig. 6).

Submicroscopically found signs of destructive changes of varying degrees in the neurons of all layers of the cerebellar cortex. There are hypochromic neurons with intensely bright karyo- and neuroplasm, which corresponds to total tigrolysis. The vast majority of neurons (especially Purkinje stem cells) were hyper- and sharply hyperchromic, which was manifested by an altered nuclearcytoplasmic ratio and significant damage to the nucleus and organelles of the neuroplasm (Fig. 7).

On the membranes of the dilated vacuole-like tubules of the granular endoplasmic reticulum there are only single ribosomes, thickened tanks of the Golgi complex, near them there are few vacuoles and bubbles. Irregularly shaped

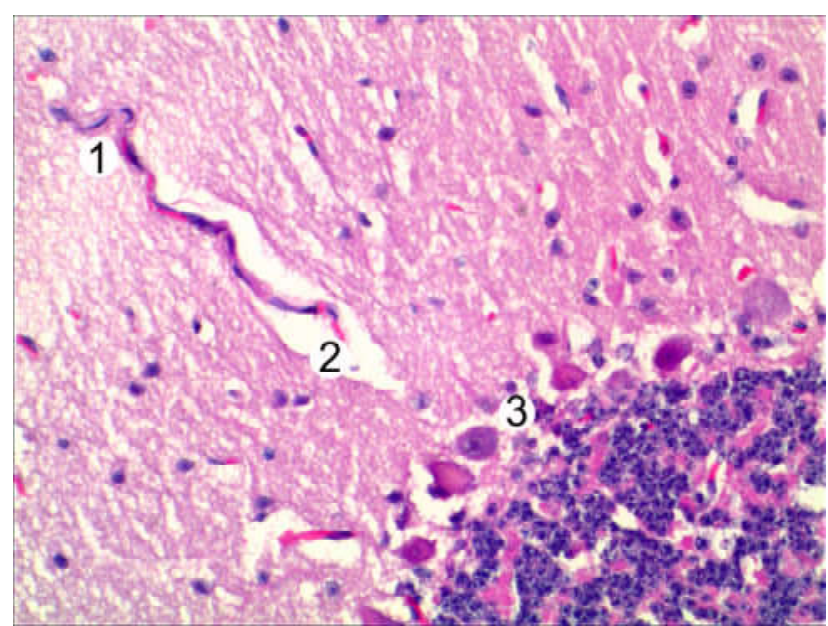

Fig. 5. Microscopic changes of the hemocapillary of the molecular layer of the cerebellar cortex 21 days after the experimental thermal injury. The lumen of the dormant capillary (1), significant perivascular edema (2), pericellular neurons edema (3). Hematoxylin-eosin. x200.

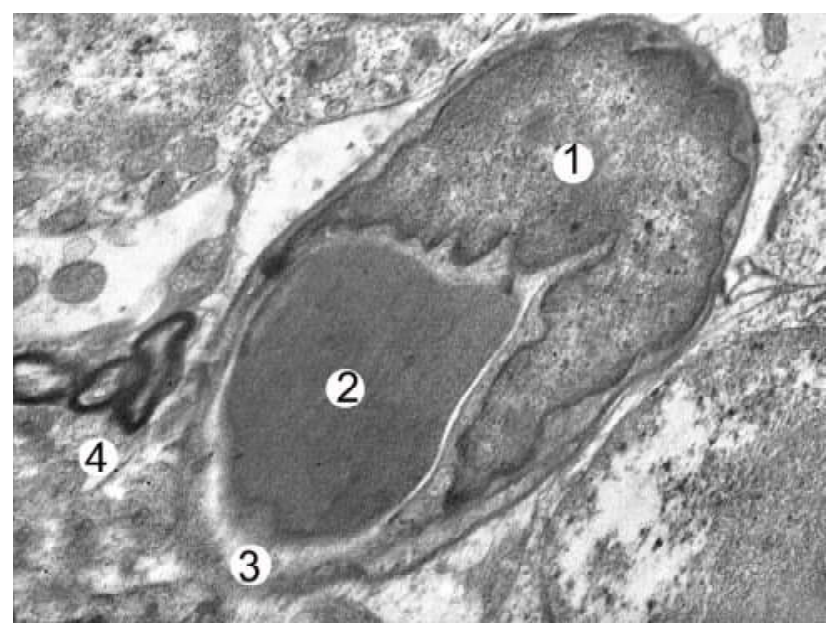

Fig. 6. Ultrastructural changes in the blood capillary of the cerebellar cortex 21 days after the experimental thermal injury. Altered nucleus of endothelial cell (1), erythrocyte in a narrow lumen (2), homogeneous, fuzzy basement membrane (3), neuropyle destruction (4). x11000. 


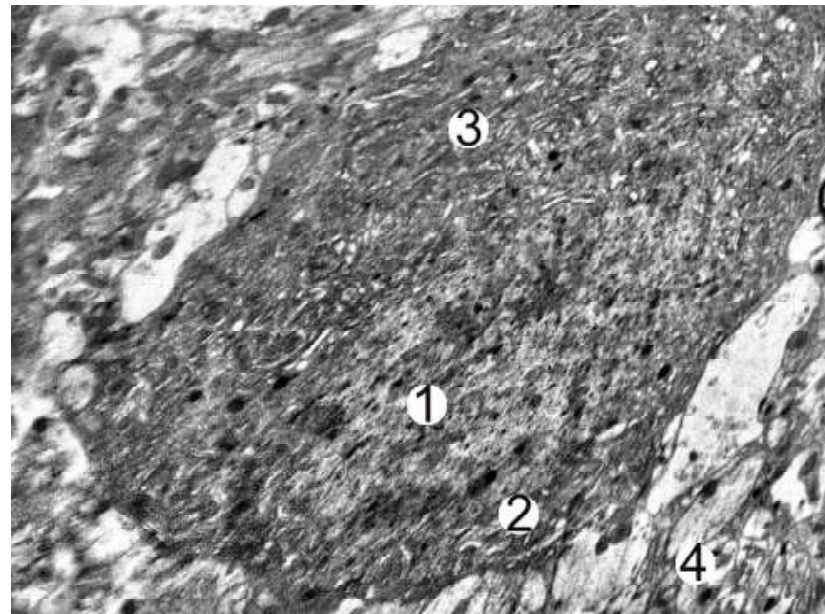

Fig. 7. Ultrastructural changes of the hyperchromic neuron of the ganglion layer of the cerebellar cortex 21 days after the experimental thermal injury. The osmophilic nucleus of the Purkinje cell (1), the fuzzy karyolemma (2), the electron-dense neuroplasm (3), and the neuropyle (4). x10000.

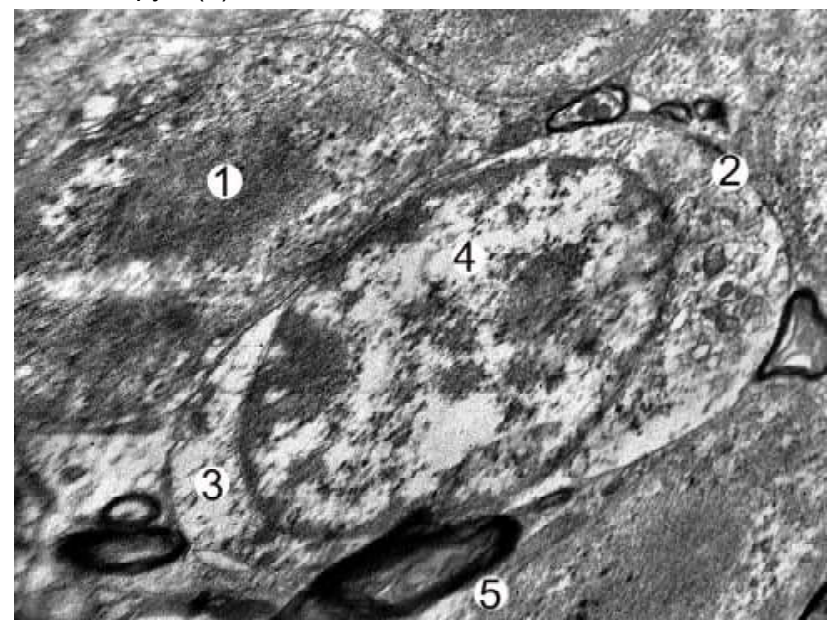

Fig. 8. Submicroscopic organization of neurons of the granular layer of the cerebellar cortex 21 days after experimental thermal trauma. Dark neuron with pyknotic nucleus (1), light neuron (2) with electron light neuro- (3) and karyoplasm (4), myelin nerve fiber (5). x9000.

mitochondria with an enlightened matrix are disorganized and are in the stage of autolysis. Molecular layer neurons are also disorganized. The cytoplasm of cells is poor in organelles and they are destructively altered, fragmented, except for single mitochondria. Nuclei of irregular shape, have indistinct homogeneous nuclear membranes, the karyoplasm is dominated by marginally placed heterochromatin, no nucleoli.

The neurons of the granular layer are also severely damaged. The shape of the cells is changed. Dark neurons with high electron density of nucleoplasm and cytoplasm and light neurons with enlightened organelle-poor karyoand neuroplasm are determined. Nuclei of irregular shape, osmophilic, compacted, no nucleoli. In the electron-dense neuroplasm of organelle cells there are few, single mitochondria with reduced cristae and osmophilic matrix are present, deformed and fragmented tubules of the endoplasmic reticulum with single ribosomes are found (Fig. 8).

\section{Discussion}

The results of micro- and submicroscopic study of neurons of the cerebellar cortex in experimental thermal trauma are to some extent consistent with the available data from the literature $[1,3,17]$.

In the works of the authors [2, 14] it was found that the action of stressors causes disorganization of microstructures and angioarchitectonics of the cerebellar cortex. We found significant neurodegenerative changes in the neurons of all layers of the cerebellar cortex. 21 days after the experimental thermal injury, the stellate and basket cells of the molecular and grain cells of the granular layers were transformed, the nuclei were pyknotized, and perivascular edema was observed in most of them. Purkinje cells of the ganglion layer are diffusely located, their order is lost, voids are often found in the place of neurons, degenerating neurons were in the stage of apoptosis and shadow cells were detected.

The authors of the study [13] believe that the formation of cell-free gaps in the ganglion layer of the cerebellar cortex is associated with the elimination of some Purkinje cells due to the action of a negative factor. Similar results were also obtained by Yu.E. Morozov with co-authors [14], who observed a complex of morphological features in neurons of the cerebellar cortex, which cause profound destructive changes. Irregularly shaped neurons with blurred contours were detected, and their processes thinned. The authors concluded that the main signs of neuronal changes in thermal trauma to the cerebellum were violations of the structure of all major elements of the cell.

To some extent, our studies are consistent with the data of M. Delion and co-authors [6]. It should be noted that among Purkinje cells there are sharply hyperchromic, which often had a narrowed shape with slender or thickened processes, and hypochromic with total dissolution of chromatophilic substance were detected. In the granular layer, according to researchers [13, 14], most grain-cells had an altered shape. Neurons, according to our research, are relatively dense, but there are areas where cells were located mosaically. Neurons of the granular layer are characterized by light and dark forms, different osmophilicity, which indicates different functional activity of cells.

Thus, the results of histological studies correlate with scientific data of other researchers and found that 21 days after severe thermal injury significantly increases the destruction of membrane structural components of neurons of the cerebellar cortex and components of the microcirculatory tract, accompanied by the development of dystrophic processes in the body.

In further researches it is planned to establish degree 
of morphological changes of a cerebellum at a thermal trauma with use of correcting factors.

\section{Conclusions}

Thus, micro- and submicroscopic studies 21 days after the experimental thermal injury, which has a pathogenic effect on the cerebellum of the affected animals, revealed significant changes in the structural rearrangement of the organ. It is established that the neurons of the cerebellar

\section{References}

[1] Ashida, R., Cerminara, N. L., Brooks, J., \& Apps, R. (2018). Principles of organization of the human cerebellum: macroand microanatomy. Handbook of Clinical Neurology, 45-58. doi: 10.1016/b978-0-444-63956-1.00003-5

[2] Bostan, A. C., \& Strick, P. L. (2018). The basal ganglia and the cerebellum: nodes in an integrated network. Nature Reviews Neuroscience, 19(6), 338-350. doi: 10.1038/s41583-0180002-7

[3] Bratby, P., Sneyd, J., \& Montgomery, J. (2016). Computational Architecture of the Granular Layer of Cerebellum-Like Structures. The Cerebellum, 16(1), 15-25. doi: 10.1007/ s12311-016-0759-z

[4] Caligiore, D., Pezzulo, G., Baldassarre, G., Bostan, A. C., Strick, P. L., Doya, K., ... Herreros, I. (2016). Consensus Paper: Towards a Systems-Level View of Cerebellar Function: the Interplay Between Cerebellum, Basal Ganglia, and Cortex. The Cerebellum, 16(1), 203-229. doi: 10.1007/s12311-0160763-3

[5] Coombes, S. A., \& Misra, G. (2016). Pain and motor processing in the human cerebellum. Pain, 157(1), 117-127. doi: 10.1097/ j.pain. 0000000000000337

[6] Delion, M., Dinomais, M., \& Mercier, P. (2016). Arteries and Veins of the Cerebellum. The Cerebellum, 16(5-6), 880-912. doi:10.1007/s12311-016-0828-3

[7] Greenhalgh, D. G. (2019). Management of Burns. New England Journal of Medicine, 380(24), 2349-2359. doi: 10.1056/ nejmra1807442

[8] Hicks, K. E., Huynh, M. N. Q., Jeschke, M., \& Malic, C. (2019). Dermal regenerative matrix use in burn patients: A systematic review. Journal of Plastic, Reconstructive \& Aesthetic Surgery, 72(11), 1741-1752. doi: 10.1016/j.bjps.2019.07.021

[9] Horalskyi, L. P., Khomych, V. T., \& Kononskyi, O. I. (2015). Fundamentals of histological technique and morphofunctionalmethods of research in normal and pathology. Zhytomyr: Polissya. http://ir.znau.edu.ua/handle/ $123456789 / 3788$

[10] Jeschke, M. G., van Baar, M. E., Choudhry, M. A., Chung, K. K., Gibran, N. S., \& Logsetty, S. (2020). Burn injury. Nature Reviews Disease Primers, 6(1). doi: 10.1038/s41572-020-0145-5 cortex undergo profound destructive-degenerative changes. Neurons of the molecular and granular layers change their shape, there is pericellular edema. Purkinje cells are dominated by sharply hyperchromic and single hypochromic neurons. Significant transformation of the structural organization of hemocapillaries of the cerebellar cortex, the development of paravasal edema, wall damage, transendothelial metabolism and significant hematoneural relationships in organ.

[11] Kearney, L., Francis, E. C., \& Clover, A. J. (2018). New technologies in global burn care - a review of recent advances. Int. J. Burns Trauma, 8(4), 77-87.

[12] Korytskyi, V. G., Nebesna, Z. M., \& Kramar, S. B. (2019). Restructuring of vessels of the thyroid gland after experimental thermal injury along with application of minced substrate of freeze-dried xenograft. World of Medicine and Biology, 68(2), 183-187. doi: 10.26724/2079-8334-2019-2-68-183-187

[13] Mateshuk-Vatseba, L. R., \& Bekesevych, A. M. (2015). Structural organization of rat cerebellar cortex under conditions of 6-week introduction of opioids. Clinical Anatomy and Operative Surgery, 14(2), 69-71.

[14] Morozov, Yu. E., Dorosheva, Zh. V., Gornostaev, D. V., Koludarova, E. M., \& Pigolkin, Yu. I. (2018). The morphological characteristic of the cerebellar cortex in the case of a burning injury. Forensic Medical Expertise, 4, 24-27. doi: 10.17116/ sudmed201861424

[15] Rabellino, D., Densmore, M., Theberge, J., McKinnon, M. C., \& Lanius, R. A. (2018). The cerebellum after trauma: Restingstate functional connectivity of the cerebellum in posttraumatic stress disorder and its dissociative subtype. Human Brain Mapping, 39(8), 3354-3374. doi:10.1002/hbm.24081

[16] Stoodley, C. J., \& Schmahmann, J. D. (2018). Functional topography of the human cerebellum. Handbook of Clinical Neurology, 59-70. doi: 10.1016/b978-0-444-63956-1.00004-7

[17] Tejiram, S., Romanowski, K. S., \& Palmieri, T. L. (2019). Initial management of severe burn injury. Current Opinion in Critical Care, 25(6), 647-652. doi: 10.1097/mcc.0000000000000662

[18] Wallauer, M. M., Huf, F., Tortorelli, L. S., Rahmeier, F. L., Carvalho, F. B., Meurer, R. T., \& da Cruz Fernandes, M. (2018). Morphological changes in the cerebellum as a result of ethanol treatment and cigarette smoke exposure: A study on astrogliosis, apoptosis and Purkinje cells. Neuroscience Letters, 672, 70-77. doi: 10.1016/j.neulet.2018.02.047

[19] Zhang, Q.-H., Hao, J.-W., Xiao-Jing, J., Guang-Lei, L., Zhou, M., \& Yao, Y.-M. (2019). Long-lasting neurobehavioral alterations in burn-injured mice resembling post-traumatic stress disorder in humans. Experimental Neurology, 113084. doi:10.1016/j.expneurol.2019.113084

\section{МІКРО- ТА СУБМІКРОСКОПІЧНІ ЗМІНИ КОРИ МОЗОЧКА ЧЕРЕЗ 21 ДОБУ ПІСЛЯ МОДЕЛЮВАННЯ ОПІКОВОГО УРАЖЕННЯ}

\section{Огінська Н.В., Небесна З.М., Гетманюк І.Б.}

Мозочок є складно організованою поліфункціональною складовою головного мозку та мішенню при численних ураженнях, тому вивчення його морфоффункціонального стану при різних патологічних станах та опіках зокрема не втрачає своєі актуальності. Метою нашого дослідження було встановити особливості мікро- та субмікроскопічних змін структурних компонентів кори мозочка через 21 добу за умов експериментальної термічної травми. Експериментальне дослідження моделювали на білих лабораторних щурах-самиях. Опік III ступеня наносили під тіопентал-натрієвим наркозом мідними пластинами, нагрітими у кип'яченій воді до температури $97-100^{\circ} \mathrm{C}$. Розміри ділянки ураження складали 18-20\% епільованої поверхні тіла щурів. Гістологічні зміни вивчали на 21 добу від початку експерименту. Напівтонкі зрізи для світлової мікроскопії забарвлювали метиленовим синім, для електронної мікроскопії отримані ультратонкі зрізи контрастували уранілацетатом та цитратом свинцю за методом Рейнольдса. За допомогою мікро- та субмікроскопічних досліджень було 
виявлено значні альтеративні зміни як нейронів усіх шарів кори мозочка так і ланок мікроциркуляторного русла органу. Нейрони дезорганізовані, форма їх змінена, відзначається низька функціональна активність за рахунок зниження площі хроматофрільної речовини. Часто наявні безклітинні ділянки у гангліонарному шарі, відзначається зміщення клітин Пуркіньє глибоко в зернистий шар, а клітини зерна різко виштовхуються до вище розташованого молекулярного шару. Таким чином, через 21 добу після експериментальної термічної травми встановлені деструктивно-дегенеративні зміни нейронів кори мозочка, паравазальний набряк та порушення трансендотеліального обміну.

Ключові слова: кора мозочка, мікро- та субмікроскопічні зміни, нейрони, термічна травма.

\section{МИКРО- И СУБМИКРОСКОПИЧЕСКИЕ ИЗМЕНЕНИЯ КОРЫ МОЗЖЕЧКА ЧЕРЕЗ 21 СУТКИ ПОСЛЕ МОДЕЛИРОВАНИЯ ОЖОГОВОГО ПОРАЖЕНИЯ \\ Оеинская Н.В., Небесна З.М., Гетманюк И.Б.}

Мозжечок является сложно организованной полифункциональной составляющей головного мозга и мищенью при многочисленных поражениях, поэтому изучение его морфоффункционального состояния при различных патологических состояниях и ожогах в частности не теряет своей актуальности. Целью нашего исследования было установить особенности микро- и субмикроскопических изменений структурных компонентов коры мозжечка через 21 день в условиях экспериментальной термической травмы. Экспериментальное исследование моделировали на белых лабораторных крысахсамцах. Ожог III степени наносили под тиопентал-натриевым наркозом медными пластинами, нагретыми в кипяченой воде до температуры $97-100^{\circ} \mathrm{C}$. Размеры участка поражения составляли 18-20\% эпилированной поверхности тела крыс. Гистологические изменения изучали на 21 сутки от начала эксперимента. Полутонкие срезы для световой микроскопии окрашивали метиленовым синим, для электронной микроскопии полученные ультратонкие срезы контрастировали уранилацетатом и цитратом свинца по методу Рейнольдса. С помощью микро- и субмикроскопических исследований были выявлены значительные альтеративные изменения как нейронов всех слоев коры мозжечка, так и звеньев микроциркуляторного русла органа. Нейроны дезорганизованы, фрорма их изменена, отмечается низкая фрункциональная активность за счет снижения площади хроматофильного вещества. Часто имеются бесклеточные участки в ганглионарном слое, отмечается смещение клеток Пуркинье глубоко в зернистый слой, а клетки зерен резко выталкиваются в выше расположенный молекулярный слой. Таким образом, через 21 день после экспериментальной термической травмы установлены деструктивно-дегенеративные изменения нейронов коры мозжечка, паравазальный отек и нарушение трансэндотелиального обмена.

Ключевые слова: кора мозжечка, микро- и субмикроскопические изменения, нейроны, термическая травма. 